\section{Diethylstilbestrol regulates trophoblast stem cell differentiation as a ligand of orphan nuclear receptor ERR $\beta$}

\author{
Gilles B. Tremblay, ${ }^{1}$ Tilo Kunath, ${ }^{2,3}$ \\ Denis Bergeron, ${ }^{1}$ Line Lapointe, ${ }^{1}$ \\ Céline Champigny, ${ }^{4}$ Jo-Ann Bader, ${ }^{4}$ \\ Janet Rossant, ${ }^{2,3}$ and Vincent Giguère ${ }^{4-6}$
}

\begin{abstract}
${ }^{1}$ Department of Research and Development, SignalGene, Inc., Montréal, Québec H2M 2N9, Canada; ${ }^{2}$ Samuel Lunenfeld Research Institute, Mount Sinai Hospital, Toronto, Ontario M5G 1X5, Canada; ${ }^{3}$ Department of Medical Genetics and Microbiology, University of Toronto, Toronto, Ontario M5S 1A8, Canada; ${ }^{4}$ Molecular Oncology Group, McGill University Health Center, Montréal, Québec H3A 1A1, Canada; ${ }^{5}$ Departments of Biochemistry, Medicine, and Oncology, McGill University, Montréal, Québec H3A 1A1, Canada
\end{abstract}

The orphan nuclear receptor ERR $\beta$ is expressed in undifferentiated trophoblast stem cell lines and extraembryonic ectoderm, and genetic ablation of ERR $\beta$ results in abnormal trophoblast proliferation and precocious differentiation toward the giant cell lineage. Here, we show that the synthetic estrogen diethylstilbestrol (DES) promotes coactivator release from ERR $\beta$ and inhibits its transcriptional activity. Strikingly, treatment of trophoblast stem cells with DES led to their differentiation toward the polyploid giant cell lineage. In addition, DEStreated pregnant mice exhibited abnormal early placenta development associated with an overabundance of trophoblast giant cells and an absence of diploid trophoblast. These results define a novel pathway for DES action and provide evidence for steroidlike control of trophoblast development.

Received December 12, 2000; revised version accepted February 7, 2001.

Nuclear receptors constitute a large family of transcription factors that mediate responses to small lipophilic hormones and play essential roles in embryonic development and maintenance of homeostasis in adult animals (Mangelsdorf et al. 1995). Orphan nuclear receptors are members of the nuclear receptor family that lack identified ligands (Giguère 1999). Recent studies have identified several natural and synthetic ligands for a number of orphan nuclear receptors, which led to the discovery of new hormone-response systems implicated in the control of cell fate, organogenesis, and basic metabolic functions (Blumberg and Evans 1998; Kliewer et al. 1999). While the estrogen-receptor-related receptor

[Key Words: Diethylstilbestrol; trophoblast; cell differentiation; ERR $\beta$ ] ${ }^{6}$ Corresponding author.

E-MAIL vgiguere@dir.molonc.mcgill.ca; FAX (514) 843-1478.

Article and publication are at www.genesdev.org/cgi/doi/10.1101/ $\operatorname{gad} .873401$.
$(\mathrm{ERR}) \alpha(\mathrm{NR} 3 \mathrm{~B} 1)$ and ERR $\beta$ (NR3B2) were the first orphan nuclear receptors identified more than a decade ago (Giguère et al. 1988), the identification of natural and synthetic ERR ligands has remained elusive. Despite being closely related to the estrogen receptors, ERRs are not activated by natural estrogens (Giguère et al. 1988). In contrast, members of the ERR family, now known to contain a third member referred to as ERR $\gamma$ (NR3B3) (Eudy et al. 1998), display various levels of constitutive activity and can interact with coactivators in the absence of ligand (Hong et al. 1999; Vanacker et al. 1999; Xie et al. 1999).

Molecular and genetic studies have shown that ERR $\beta$ plays an important role in early placentation. ERR $\beta$ is expressed in undifferentiated trophoblast stem cell lines (Tanaka et al. 1998) and in a subset of cells in extraembryonic ectoderm destined to make up the chorion (Pettersson et al. 1996; Luo et al. 1997). Genetic ablation of ERR $\beta$ in the mouse results in abnormal chorion formation followed by failure of diploid trophoblast self-renewal and an increase in trophoblast giant cells (Luo et al. 1997). Thus, ERR $\beta$ is essential for normal placental formation, and pharmacological modulation of its activity could influence reproductive function.

Diethylstilbestrol (DES) is a potent synthetic estrogen that was used clinically for the prevention of spontaneous abortions from the 1940s to 1971 (Smith 1948). The mechanism of action and factual effectiveness of DES as an antiabortive agent were never demonstrated. However, in utero exposure to pharmacological doses of DES was shown to be associated with adverse effects on the reproductive tract of both male and female offspring as well as with increasing cases of a vaginal clear-cell adenocarcinoma (Marselos and Tomatis 1992). The teratogenicity, reproductive toxicity, and carcinogenicity of DES in humans is believed to be transduced via the classic estrogen receptors ER $\alpha$ (NR3A1) and ER $\beta$ (NR3A2) (Greco et al. 1993; Couse and Korach 1999). DES has also been shown to induce placental changes that include a reduction of the labyrinthine region and accumulation of trophoblast giant cells in mid- and late-gestation in mice (Scott and Adejokun 1980). These effects are unlikely to involve the classic estrogen receptors as genetic ablation of both receptors, singly or in combination, did not reveal a role for these receptors in placentation (Couse and Korach 1999).

In this study, we demonstrate that DES interacts with $\mathrm{ERR} \alpha, \mathrm{ERR} \beta$, and ERR $\gamma$ to suppress coactivator binding and transcription from a reporter gene, and that the synthetic estrogen controls the differentiation of trophoblast cells in culture and in utero. Taken together, these results show that DES can directly modulate early placentation and define the orphan nuclear receptors ERRs as a novel signaling pathway for DES action.

\section{Results and Discussion}

To search for ERR ligands, we adapted a nuclear receptor-coactivator interaction assay using fluorescence reso- 
nance energy transfer (FRET; Zhou et al. 1998). The receptor-interacting domain (RID) of the coactivator GRIP1 (Hong et al. 1996) was expressed, biotinylated, and purified from $E$. coli extracts and shown to interact significantly with purified GST-ER $\alpha$ only in the presence of estradiol (Fig. 1A, left). In contrast, all three ERR isoforms displayed specific interaction with the RID domain of GRIP1 in absence of ligand, the strongest interactions being observed with ERR $\beta$ and ERR $\gamma$ (Fig. 1A, right). Because ERRs are most closely related to the estrogen receptors, we hypothesized that their putative ligands might share some structural features with estrogen-like compounds. Therefore, several compounds in-

A

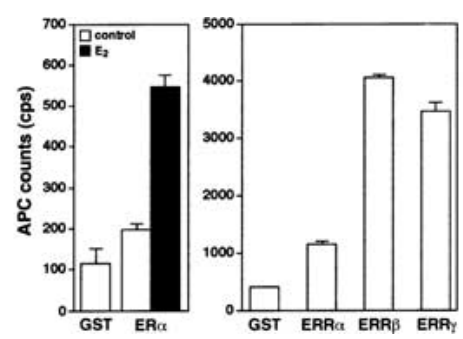

B

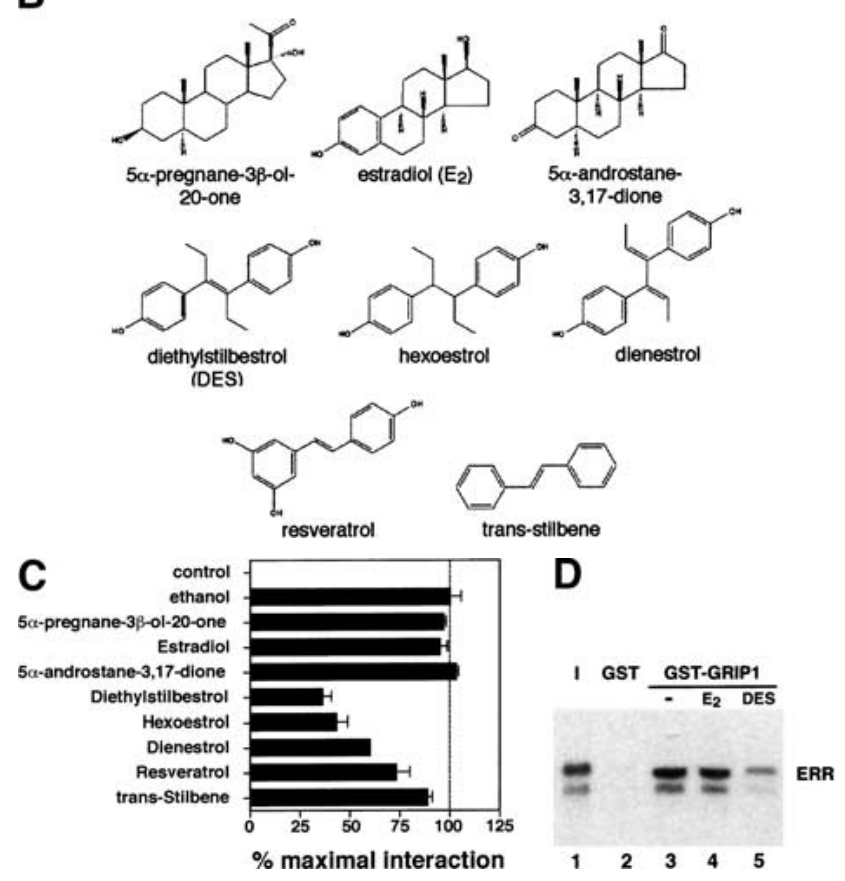

E

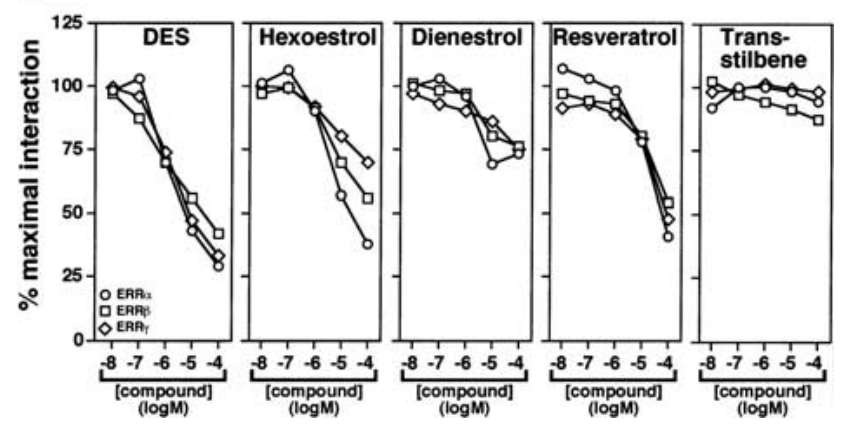

cluding substituted estradiols, pregnanes, androstanes, and some synthetic estrogens were tested for both stimulatory and inhibitory activity in this assay (Fig. 1B). Remarkably, the synthetic estrogen DES $(10 \mu \mathrm{M})$ was able to inhibit the GRIP1-ERR $\alpha$ interaction by $65 \%-70 \%$ (Fig. 1C). To investigate further the structure-activity relation of coactivator release from $\operatorname{ERR} \alpha$, we tested a number of molecules related to DES for their ability to release GRIP1 (Fig. 1C). Closely related compounds such as hexoestrol and dienestrol also had significant activity, although not as potent as DES. Conversely, lack of the extreme hydroxyl groups, as in trans-stilbene, resulted in loss of inhibitory activity in this assay. In addition, a shortened biphenol such as bis-phenol A was also unable to disrupt the ERR $\alpha-$ GRIP1 interaction (data not shown) demonstrating that a minimal molecular length is required for this activity. Interestingly, the molecules that inhibited the ERR $\alpha-$ GRIP1 interaction had the opposing effect on $\mathrm{ER} \alpha$ (data not shown). This observation indicates clearly the existence of structural and functional kinship between the two subfamilies of nuclear receptors. Toxaphene and chlordane, two organochlorine pesticides recently described as antagonists of ERR $\alpha$ in a cell-based transfection assay (Yang and Chen 1999) failed to disrupt ERR $\alpha$-GRIP interaction in this assay and were not studied further. Next, we investigated whether the inhibitory effect of DES on ERR could be observed in a standard GST pull-down assay. The constitutive interaction of ERR with GRIP1 was unaffected by the presence of estradiol $\left(E_{2}\right)$ but was considerably reduced upon treatment with DES (Fig. 1D). We also tested whether DES and related compounds were able to influence coactivator binding with all three ERR isoforms. GST-

Figure 1. DES interacts with $E R R \alpha, E R R \beta$, and ERR $\gamma$ and promotes the release of a GRIP1 RID fragment. (A) FRET assays were used to screen for compounds that could either inhibit or stimulate receptor-coactivator interactions. Biotinylated GRIP1/RID was incubated in the absence or presence of GSTER $\alpha$ or GST-ERR $\alpha$, GST-ERR $\beta$ and GST-ERR $\gamma$ and energy transfer measured by time-resolve fluorescence. ER $\alpha$ required $\mathrm{E}_{2}\left(10^{-8} \mathrm{M}\right)$ for maximal interaction whereas the ERRs interacted with GRIP1/RID constitutively in this assay. All data are expressed as counts per second \pm S.E.M. $(B)$ Chemical structures of selected steroids and DES-like compounds used in this report. (C) Ability of selected compounds to inhibit ERR $\alpha$ interactions with GRIP1/RID in a FRET assay. All compounds were tested at $10 \mu \mathrm{M}$. The sample containing ethanol represents $100 \%$ interaction.. All data are expressed as the percentage of the maximal interaction \pm S.E.M. $(D)$ DES inhibits interaction between ERR $\gamma$ and GRIP1/RID in a GST pull-down assay. Purified GSTGRIP1/RID was incubated with $\left[{ }^{35} \mathrm{~S}\right]$ methionine-labeled ERR $\gamma$ in the presence of ethanol (lane 3), $1 \mu \mathrm{M} \mathrm{E} \mathrm{E}_{2}$ (lane 4) or $10 \mu \mathrm{M}$ DES (lane 5), washed of unbound proteins, electrophoresed on a polyacrylamide gel and exposed to film overnight. (Input; lane 1) $10 \%$ of the total labeled protein used in each binding reaction; (GST; lane 2) negative control containing an equal amount of GST protein alone. (E) Dose-response study of the inhibition of ERR-GRIP1/RID interactions by DES, hexoestrol, dienestrol, resveratrol, and trans-stilbene. Maximal interaction was set as the interaction between receptor and coactivator in the presence of ethanol. 
$\mathrm{ERR} \alpha, \mathrm{GST}-\mathrm{ERR} \beta$, and GST-ERR $\gamma$ fusion proteins were subjected to FRET interaction assays, and the interaction with GRIP1 was found to be inhibited by DES for all three isoforms (Fig. 1E). Furthermore, the inhibition was dose-dependent and half-maximal inhibition occurred at $\sim 1 \mu \mathrm{M}$ for $\mathrm{ERR} \alpha, \mathrm{ERR} \beta$, and ERR $\gamma$. The potency of the other related compounds was also determined but neither hexoestrol, dienestrol, nor resveratrol were as efficient as DES in inhibiting the ERR-GRIP1 interaction (Fig. 1E). Trans-stilbene, as indicated by our initial experiments, had no significant effect on the FRET interaction even at the highest concentration used (Fig. 1E). The $\mathrm{IC}_{50}$ of $1 \mu \mathrm{M}$ for DES is similar to or less than the $\mathrm{uM} \mathrm{IC}_{50}$ values reported for the ligands of numerous other orphan nuclear receptors (Giguère 1999). DES, used at a concentration of $50 \mu \mathrm{M}$, has been reported to activate the human steroid and xenobiotic receptor (SXR;NR1I2) but not the mouse homolog PXR (Blumberg et al. 1998). We have also failed to detect significant DES activity on a large series of nuclear receptors (data not shown), including PPAR $\gamma$, which plays a role in placenta development (see below). To confirm the specificity of DES inverse agonist activity on nuclear receptors, we also tested whether DES could influence the binding of steroid receptor coactivator-1 (SRC-1) to CAR (NR1I3), an orphan nuclear receptor whose interaction with coactivators is negatively regulated by androstane metabolites (Forman et al. 1998). DES had no effect on the constitutive CAR-SRC-1 complex (data not shown).

The inhibitory effect of DES on $\operatorname{ERR} \alpha, E R R \beta$, and ERR $\gamma$ activity was assessed in cells by transient transfection assays. Expression vectors for $\operatorname{ERR} \alpha, E R R \beta$, and ERR $\gamma$ were transfected into COS-1 cells in the presence of a luciferase reporter plasmid under the control of an estrogen-response element, which supports ERR transactivation (Xie et al. 1999). When transfected alone, $\mathrm{ERR} \alpha$ had small but detectable transcriptional activity whereas ERR $\beta$ and ERR $\gamma$ displayed constitutive activity on this reporter gene with a 3.5- and 6-fold induction of transcription, respectively, compared with cells transfected with empty vector (Fig. 2A, left). As observed with the FRET interaction assays, there was no change in receptor activity when the cells were treated with $\mathrm{E}_{2}$. In contrast, treatment of the transfected cells with DES resulted in total inhibition of ERR transcriptional activity (Fig. 2A, left). Next, we investigated whether the ERRcoactivator interaction could be disrupted by DES in vivo. We tested this directly by a mammalian one-hybrid assay in the presence of full-length $E R R \alpha, E R R \beta$, and ERR $\gamma$ and the $C$ terminus of SRC-1a (residues 880-1454) linked to the transactivation domain of VP16. In the presence of VP16-SRC1a, the transcriptional activity of all three ERR isoforms could be stimulated, especially that of ERR $\beta$ and ERR $\gamma$ with a 15- to 18 -fold enhancement in the presence of the hybrid protein (Fig. 2A, middle). Again, DES could successfully inhibit the stimulatory effect of VP16-SRC-1a on ERR $\alpha, E R R \beta$, and ERR $\gamma$ whereas $E_{2}$ had no effect. These results indicate that DES can promote the release of coactivator from $\mathrm{ERR} \alpha, \mathrm{ERR} \beta$, and ERR $\gamma$ in vivo. As a control, ER $\alpha$ was
A
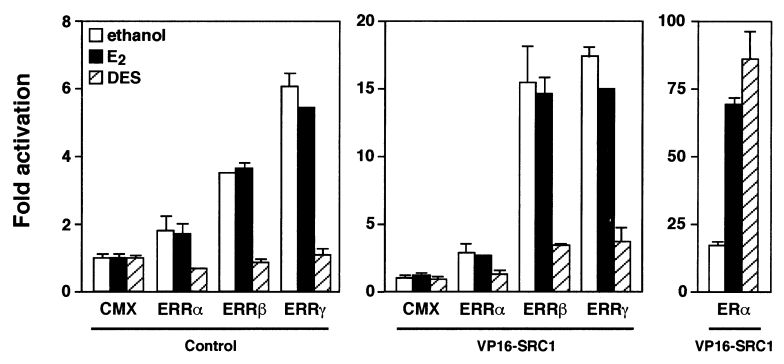

B

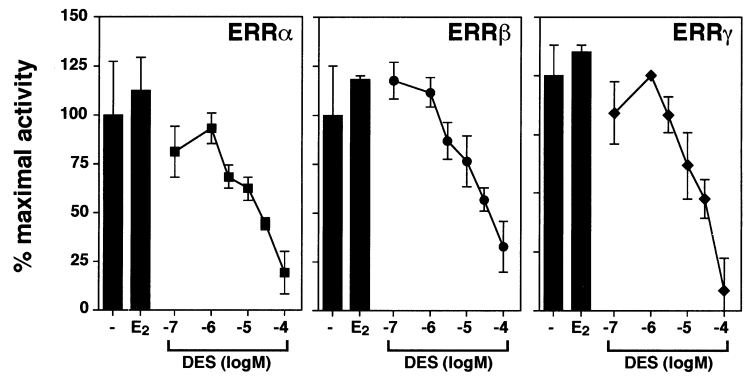

Figure 2. DES inhibits the constitutive transcriptional activity of ERR $\alpha, E R R \beta$ and ERR $\gamma$. (A) COS-1 cells were transfected with $100 \mathrm{ng}$ each of pCMX-ERR or pCMX-ER $\alpha$ and either pCMXVP16 (left) or pCMX-VP16-SRC1 (middle) fusion plasmids as indicated and treated with $0.1 \%$ ethanol (vehicle), $100 \mathrm{nM} \mathrm{E}_{2}$ or $10 \mu \mathrm{M}$ DES. Luciferase activity was determined and expressed as fold activation over basal transcription in the presence of empty expression vectors. $(B)$ Dose-dependent inhibition of $\mathrm{ERR} \alpha, \mathrm{ERR} \beta$ and ERR $\gamma$ transcriptional activity by DES. The data are presented as the percentage of the remaining activity in the presence of $0.1 \%$ ethanol (vehicle). $E_{2}(10 \mu \mathrm{M})$ was used as a control. Results represent the mean of at least three duplicate transfections \pm S.E.M.

also transfected and, as expected, DES acted as an agonist in the presence of ER $\alpha$ (Fig. 2A, right). To determine the in vivo potency of DES, plasmids expressing $E R R \alpha$, ERR $\beta$, and ERR $\gamma$ were transfected into COS-1 cells, which were then treated in a dose-dependent manner with increasing concentrations of DES. The transcriptional activity of all three isoforms of ERRs could be inhibited completely by DES with a half-maximal inhibition observed between 5 and $15 \mu \mathrm{M}$ (Fig. 2B). Similar results were obtained in HeLa cells (data not shown). We have also examined whether DES promotes corepressor interaction with ERR family members. We could not detect significant physical interaction between the corepressors $\mathrm{N}-\mathrm{CoR}$ or SMRT and members of the ERR family in the presence or the absence of DES (data not shown).

We have shown previously that ERR $\beta$ is essential for normal trophoblast cell proliferation and differentiation during early placentation in the mouse (Luo et al. 1997). More specifically, the absence of ERR $\beta$ is associated with an overabundance of trophoblast giant cells and a severe deficiency of diploid trophoblast. The recent and successful derivation of trophoblast stem cell lines offers for the first time a model system to dissect the function of signaling pathways that are crucial to the development of the mammalian trophoblast lineage (Tanaka et al. 1998). In this system, the presence of fibroblast growth factor 4 (FGF4) promotes cells derived from the 
extraembryonic ectoderm to proliferate in an undifferentiated state. Removal of FGF4 results in a rapid decline in proliferation and differentiation from a tight epithelial morphology toward the giant cell phenotype. Recent attempts to derive trophoblast stem cell lines from ERR $\beta$ mutant embryos were unsuccessful, suggesting that the constitutive activity of ERR $\beta$, which is expressed in undifferentiated cells, could be involved in maintaining trophoblast stem cells in a proliferative state. To test this hypothesis, we subjected trophoblast stem cell cultures to treatment with DES and $\mathrm{E}_{2}$ as a control in the presence of FGF4. A major difference in cell morphology was observed upon treatment with $10 \mu \mathrm{M}$ DES (Fig. 3A, bottom). Large nuclei and distinct cell borders characteristic of trophoblast giant cells could be observed in cells treated with DES (Fig. 3A, bottom) whereas cells treated with vehicle (ethanol) or $\mathrm{E}_{2}$ (Fig. $3 \mathrm{~A}$, top and middle, respectively) maintained a tight epithelial morphology. The ploidy of the cells was determined by fluorescenceactivated cell sorting (FACS) analysis. The profile for cells maintained in vehicle or $\mathrm{E}_{2}$ (Fig. $3 \mathrm{~B}$, top and middle, respectively) revealed prominent peaks at $2 \mathrm{~N}$ (diploid) and $4 \mathrm{~N}$ (tetraploid), with a small percentage of higher
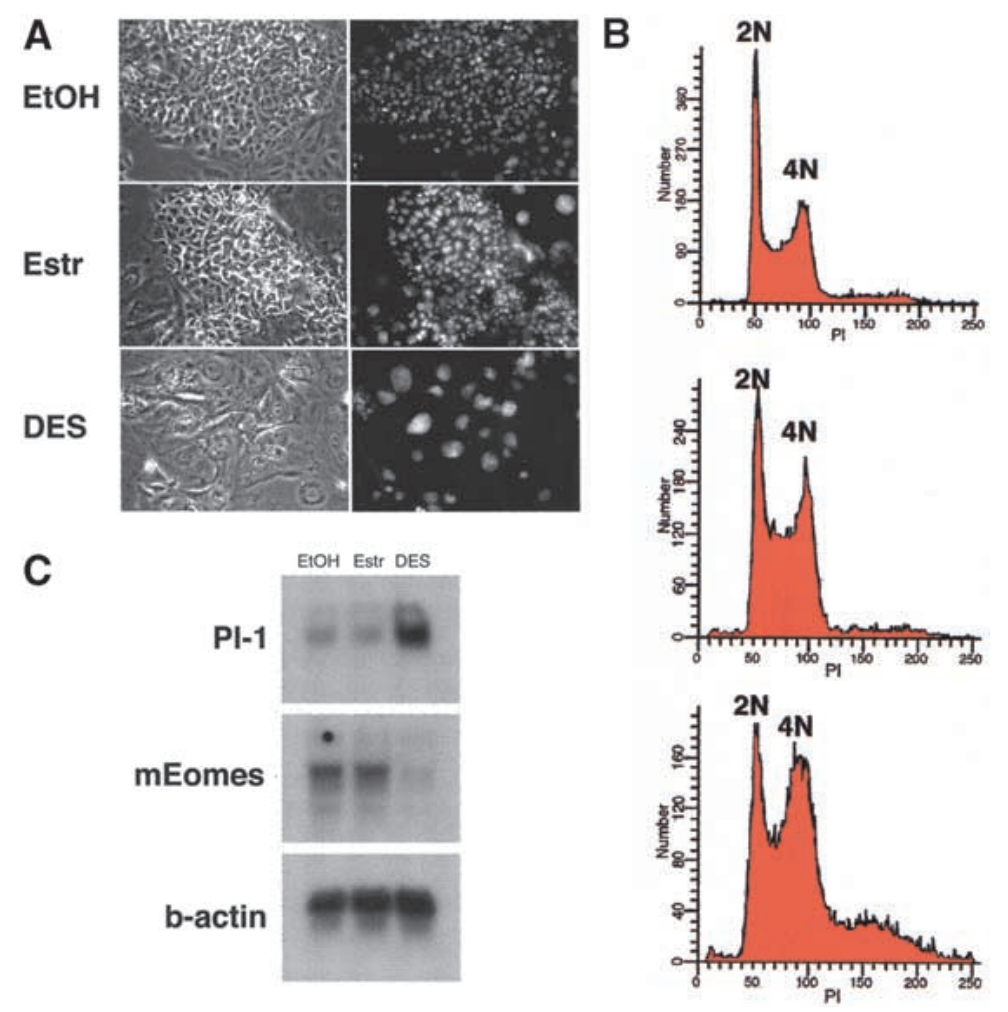

Figure 3. Effect of DES on trophoblast stem cell lines in culture. $(A)$ Representative microphotographs of trophoblast stem cells cultured in the presence of ethanol (top), $10 \mu \mathrm{M} \mathrm{E}_{2}$ (middle) and $10 \mu \mathrm{M}$ DES (bottom). Large nuclei stained with Hoechst 33342 (right) are characteristic of giant cells. (B) DNA content was analyzed by flow cytometry studies of cells stained with prodidium iodide $(\mathrm{PI})$. Trophoblast stem cells were analyzed $6 \mathrm{~d}$ after treatment. Diploid $(2 \mathrm{~N})$ and tetraploid $(4 \mathrm{~N})$ DNA contents are indicated. $(C)$ RNA analysis of trophoblast stem cells cultured in the presence and absence of estradiol or DES. The cells were treated for $4 \mathrm{~d}$ with vehicle alone $(\mathrm{EtOH})$, or $\mathrm{E}_{2}$ (estr) and DES at a final concentration of $10 \mu \mathrm{M}$. ploidy cells as observed previously (Tanaka et al. 1998). Upon treatment with DES a shift toward higher ploidy occurred, with a concurrent decrease in diploid cell content after $6 \mathrm{~d}$ in culture (Fig. 3B, bottom). In addition, DES treatment led to a dramatic decrease in trophoblast stem cell proliferation (data not shown). Genetic markers were also used to characterize the DES-induced differentiation of the trophoblast stem cells. The mouse homolog of eomesodermin (mEomes), which is highly expressed in trophoblast stem cells (Ciruna and Rossant 1999), is down-regulated upon DES treatment (Fig 3C). In contrast, placental lactogen 1 (Pl-1), a marker for giant cells (Faria et al. 1990), was induced in cultures after addition of DES. These events were observed before morphological changes were evident and indicate that DES directly induces the differentiation of trophoblast stem cells to giant cells in culture even in the presence of FGF4.

Treatment of mice with DES during mid- to late-gestation induces placental changes that include reduction of the labyrinthine region and accumulation of trophoblast giant cells (Scott and Adejokun 1980). To examine whether DES can affect early development of the placenta at a time when ERR $\beta$ expression is essential for this process, we treated pregnant mice from 4.5 to $8.5 \mathrm{~d}$ post coitum (d.p.c.) with DES. Administration of DES to pregnant mice produced a phenotype reminiscent of the ERR $\beta$ null mutant. DES-treated placentas exhibited a marked reduction or absence of the labyrinth and spongiotrophoblast layers with a concomitant increase in the giant cell layer (Fig. 4, bottom). $\mathrm{E}_{2}$ treatment did not induce changes in trophoblast morphology (data not shown).

The results presented here strongly support the hypothesis that DES, acting in the manner of an inverse agonist, regulates the transcriptional activity of the orphan nuclear receptor ERR $\beta$ and influences early development of the placenta through controlling trophoblast stem cell differentiation. Whereas phenotypic analyses of embryos carrying null mutations of both $\mathrm{RXR} \alpha$ (NR2B1) and RXR $\beta$ (NR2B2) or PPAR $\gamma$ (NR1C3) alone showed that RXR-PPAR $\gamma$ complexes are essential for normal vascularization of the placenta and its proper development (Barak et al. 1999; Wendling et al. 1999|, PPAR $\gamma$ itself and putative RXR ligands are dispensable for the establishment of trophoblast lineage identity. Taken together with the results of the phenotypic analysis of steroid receptor, null mice demonstrating no role for these receptors in early placentation (Cole et al. 1995; Lydon et al. 1995; Berger et al. 1998; Couse and Korach 1999; Xie et al. 2000), these studies strengthen our conclusion that the effects of DES on early placentation are transduced via ERR $\beta$ as the inverse agonist/ antagonist ligand mimics the placental phenotype observed in ERR $\beta$ null mice (Luo et al. 1997). 

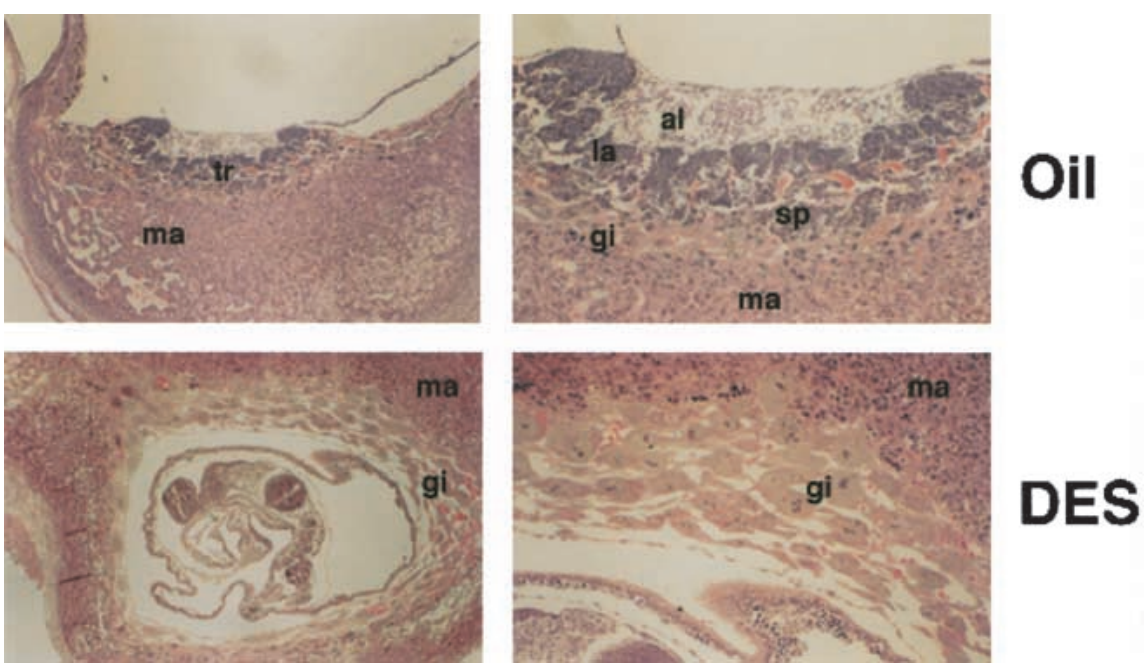

Figure 4. Effect of DES on the morphology of trophoblast tissues. Pregnant mice were treated daily with oil or DES on day 4.5 to 8.5 d.p.c. and placentas were examined at 9.5 d.p.c. In the treated animals (DES), diploid trophoblast cells were absent and secondary giant cells formed multiple layers. Panels at right are higher magnification of panels at left. (al) Allantois; (gi) giant cells; (la) labyrinthine trophoblast; (ma) maternal deciduas; (sp) spongiotrophoblast; (tr) trophoblast.

Our studies suggest further that in addition to FGF4 (Tanaka et al. 1998), natural ERR ligands may be essential components of the embryonic signal required for proper control of trophoblast stem cell proliferation. These observations not only reveal a novel pharmacological pathway for DES action but also suggest that a steroid hormone-dependent mechanism may regulate early placentation. The availability of high throughput screening assays and a well-defined biological model system should greatly facilitate the identification of natural ERR ligands and open new avenues for identifying gene networks that are crucial to the development of the placenta.

\section{Materials and methods}

Fluorescence resonance energy transfer (FRET)

Interactions between receptor and coactivator domains were monitored by use of FRET technology (Zhou et al. 1998). To prepare the GST-ERR proteins, the ligand-binding domains of human $\operatorname{ERR} \alpha$, mouse ERR $\beta$, and mouse ERR $\gamma$ were amplified by PCR and subcloned in-frame into pGEX2T (Pharmacia) and transformed into Escherichia coli strain BL21/DE3. pGEX-ER $\alpha$ has been described (Tremblay et al. 1997). Bacterial cultures were grown, and fusion proteins expressed and purified with GST-Sepharose 4B (Pharmacia). The RID (amino acids 565-789) of mouse GRIP1 (Hong et al. 1996) was amplified by PCR and subcloned into the prokaryotic expression vector pCAL-n (Stratagene). The N-terminal calmodulinbinding peptide tag was used to purify the fusion protein with a calmodulin resin. In addition, a biotinylation signal peptide (Schatz 1993) was inserted at the $\mathrm{C}$ terminus of the fusion protein to allow for simultaneous biotinylation of the protein in E. coli. Briefly, the tagged GRIP1/RID and the plasmid pACYC184-birA (Avidity), which expresses biotin ligase, were co-transformed into BL21/DE3, and expression of the fusion protein and biotin ligase were induced with $0.4 \mathrm{mM}$ IPTG in the presence of 50 $\mu \mathrm{M}$ biotin. The biotinylated GRIP1/RID was purified with the calmodulin resin and verified for the presence of a biotin by Western blotting analysis using streptavidin-POD (Boehringer Mannheim). Purified proteins were quantified by standard methods and stored at $-80^{\circ} \mathrm{C}$ in $10 \%$ glycerol until use. LANCE europium (Eu)-labeled anti-GST antibody and allophycocyanin (APC)-conjugated streptavidin were purchased from EG\&G Wallac. The FRET assays were carried out in $125 \mathrm{mM} \mathrm{KCl,} 50 \mathrm{mM}$
HEPES (pH 7.8), 0.1\% 3-[(3-cholamindopropyl) dimethyl-ammonia]-1-propanesulfonate (CHAPS) and $0.1 \%$ dry milk containing $10 \mathrm{nM}$ GST-ERR(LBD), $20 \mathrm{nM}$ biotinylated GRIP1/ RID, $2 \mathrm{nM}$ anti-GST-Eu and $5 \mu \mathrm{g} / \mathrm{mL}$ streptavidin-APC. The total volume of the reaction was $100 \mu \mathrm{L}$, and steroids were added as indicated. Reactions were incubated at $4^{\circ} \mathrm{C}$ overnight and the fluorescence measured in black 96-well plates with the Victor $^{2}$ in time-resolve fluorescence mode.

Plasmids and cell transfection

All ERR cDNAs were cloned into the expression vector pCMX. The luciferase reporter plasmid utilized in all transfection assays, vERE-tkLuc, contained three copies of a consensus estrogen response element (Klein-Hitpass et al. 1989) cloned into ptkLuc. CMXVP16-SRCla $\mathrm{a}_{880-1454}$ was constructed by amplification of the region of the human SRCla cDNA (Oñate et al. 1995) encoding amino acids 880-1454 and the fragment subcloned into pCMX-VP16 downstream of VP16. All cell lines used in the study were obtained from American Type Culture Collection and maintained in Dulbecco's Modified Eagle Medium (DMEM) with $10 \%$ fetal bovine serum. Twenty four hours prior to transfection, cells were seeded in 12-well plates and grown in phenol red-free DMEM containing charcoal-treated fetal bovine serum. Cells were transfected with $100 \mathrm{ng}$ of expression, $1 \mu \mathrm{g}$ of reporter, and 0.5 $\mu \mathrm{g}$ of CMX- $\beta$ gal plasmids by use of either Lipofectamine 2000 or Lipofectin Reagent for COS-1 or HeLa cells, respectively. Cells were maintained in the presence of liposomes for $24 \mathrm{~h}$ and treated with steroids for an additional $24 \mathrm{~h}$ before being harvested in potassium phosphate buffer containing $1 \%$ Triton X-100. Luciferase activity was determined by use of Steady-Glo (Promega) and values read with the Victor ${ }^{2}$ in the luminescence mode. The transfection was normalized to the $\beta$-galactosidase activity of each sample. All results represent experiments conducted in duplicate at least three times.

Trophoblast stem cell cultures

Trophoblast stem cells were grown for $6 \mathrm{~d}$ in TS + F4H medium in the presence of DES $(10 \mu \mathrm{M}), \mathrm{E}_{2}(10 \mu \mathrm{M})$, or the vehicle (ethanol). TS + F4H medium is RPMI 1640 supplemented with $20 \%$ fetal bovine serum, 1 $\mathrm{mM}$ sodium pyruvate, $100 \mathrm{mM} \beta$-mercaptoethanol, $2 \mathrm{mM}$ L-glutamine, penicillin/streptomycin $(50 \mathrm{mg} / \mathrm{mL}$ each), $25 \mathrm{ng} / \mathrm{mL}$ human recombinant FGF4, and $1 \mathrm{mg} / \mathrm{mL}$ heparin. The cells were grown on cover slips, fixed in $3.7 \%$ formaldehyde, rinsed with PBS, and stained with Hoechst 33342 $(1 \mu \mathrm{M} / \mathrm{mL}$, Molecular Probes, Eugene, OR) for $10 \mathrm{~min}$ at room temperature. The stained cells were rinsed with PBS and mounted on slides. Phase-contrast and UV excitation optics were used to visualize the cells and nuclei, respectively. Cell fluorescence was measured by a flow cytometer with an argon ion laser $(488 \mathrm{~nm}$ ) as described (Darzynkiewicz and Juan 1997).

\section{RNA analysis}

Total RNA was prepared from cells with TRizol (GIBCO BRL) according to the manufacturer's instructions. Northern (RNA) blotting was performed by a standard protocol with antisense RNA probes for eomesodermin, Pl-1, and $\beta$-actin as described previously (Tanaka et al. 1998).

DES treatment and histological studies

DES was given to pregnant mice by oral gavage (500 $\mu$ g daily). Mice were treated daily from 4.5 to 8.5 d.p.c. and sacrificed the following day. Embryos and trophoblast tissues were fixed in $4 \%$ paraformaldehyde, dehydrated, and embedded in paraffin. Sections $(7 \mu \mathrm{m})$ were stained with haematoxylin and eosin.

\section{Acknowledgments}

We thank B.W. O'Malley and M.R. Stallcup for SRC-1 and GRIP1 plasmids, respectively, G. Knowles for FACS analyses, and D. Dufort for histological analyses. This work was supported by the Canadian Insti- 
tutes for Health Research (CIHR) and SignalGene, Inc. T.K. is the recipient of a CIHR studentship, V.G. is a CIHR senior scientist, and J.R. is a CIHR distinguished scientist and a Howard Hughes international scholar.

The publication costs of this article were defrayed in part by payment of page charges. This article must therefore be hereby marked "advertisement" in accordance with 18 USC section 1734 solely to indicate this fact.

\section{References}

Barak, Y., Nelson, M.C., Ong, E.S., Jones, Y.Z., Ruiz-Lozano, P., Chien, K.R., Koder, A., and Evans, R.M. 1999. PPAR $\gamma$ is required for placental, cardiac, and adipose tissue development. Mol. Cell 4: 585-595.

Berger, S., Bleich, M., Schmid, W., Cole, T.J., Peters, J., Watanabe, H., Kriz, W., Warth, R., Greger, R., and Schütz G. 1998. Mineralocorticoid receptor knockout mice: Pathophysiology of $\mathrm{Na}^{+}$metabolism. Proc. Natl. Acad. Sci. 95: 9424-9429.

Blumberg, B. and Evans, R.M. 1998. Orphan nuclear receptors: New ligands and new possibilities. Genes \& Dev. 12: 3149-3155.

Blumberg, B., Sabbagh, Jr., W., Juguilon, H., Bolado, Jr., J., van Meter, C.M., Ong, E.S., and Evans, R.M. 1998. SXR, a novel steroid and xenobiotic-sensing nuclear receptor. Genes \& Dev. 12: 3195-3205.

Ciruna, B.G. and Rossant, J. 1999. Expression of the T-box gene Eomesodermin during early mouse development. Mech. Dev. 81: 199-203.

Cole, T.J., Blendy, J.A., Monaghan, A.P., Krieglstein, K., Schmid, W., Aguzzi, A., Fantuzzi, G., Hummler, E., Unsicker, K., and Schütz, G. 1995. Targeted disruption of the glucocorticoid receptor gene blocks adrenergic chromaffin cell development and severely retards lung maturation. Genes \& Dev. 9: 1608-1621.

Couse, J.F. and Korach, K.S. 1999. Estrogen receptor null mice: What have we learned and where will they lead us? Endocr. Rev. 20: 358-417.

Darzynkiewicz, Z. and Juan, G.. 1997. In Current protocols in cytometry, pp. 7.5.2-7.5.3. John Wiley \& Sons, New York.

Eudy, J.D., Yao, S., Weston, M.D., Ma-Edmonds, M., Talmage, C.B., Cheng, J.J., Kimberling, W.J., and Sumegi, J. 1998. Isolation of a gene encoding a novel member of the nuclear receptor superfamily from the critical region of Usher syndrome type IIa at 1q41. Genomics 50: 382-384.

Faria, T.N., Deb, S., Kwok, S.C., Talamantes, F., and Soares, M.J. 1990. Ontogeny of placental lactogen-I and placental lactogen-II expression in the developing rat placenta. Dev. Biol. 141: 279-291.

Forman, B.M., Tzameli, I., Choi, H.-S., Chen, J., Simha, D., Seol, W., Evans, R.M., and Moore, D.D. 1998. Androstane metabolites bind to and deactivate the nuclear receptor CAR-b. Nature 395: 612-615.

Giguère, V. 1999. Orphan nuclear receptors: From gene to function. Endocrinol. Rev. 20: 689-725.

Giguère, V., Yang, N., Segui, P., and Evans, R.M. 1988. Identification of a new class of steroid hormone receptors. Nature 331: 91-94.

Greco, T.L., Duello, T.M., and Gorski, J. 1993. Estrogen receptors, estradiol, and diethylstilbestrol in early development: The mouse as a model for the study of estrogen receptors and estrogen sensitivity in embryonic development of male and female reproductive tracts. Endocrinol. Rev. 14: 59-71.

Hong, H., Kohli, K., Trivedi, A., Johnson, D.L., and Stallcup, M.R. 1996. GRIP1, a novel mouse protein that serves as a transcriptional coactivator in yeast for the hormone binding domains of steroid receptors. Proc. Nat1. Acad. Sci. 93: 4948-4952.

Hong, H., Yang, L., and Stallcup, M.R. 1999. Hormone-independent transcriptional activation and coactivator binding by novel orphan nuclear receptor ERR3. J. Biol. Chem. 274: 22618-22626.

Klein-Hitpass, L., Tsai, S.Y., Greene, G.L., Clark, J.H., Tsai, M.-J., and B.W. O'Malley, B.W. 1989. Specific binding of estrogen receptor to the estrogen reponse element. Mol. Cell. Biol. 9: 43-49.

Kliewer, S.A., Lehmann, J.M., and Willson, T.M. 1999. Orphan nuclear receptors: Shifting endocrinology into reverse. Science 284: 757-760.

Luo, J., Sladek, R., Bader, J.-A., Rossant, J., and Giguère, V. 1997. Placental abnormalities in mouse embryos lacking orphan nuclear receptor ERRß. Nature 388: 778-782.

Lydon, J.P., Demayo, F.J., Funk, C.R., Mani, S.K., Hughes, A.R., Montgomery, C.A., Shyamala, G., Conneely, O.M., and O'Malley, B.W. 1995. Mice lacking progesterone receptor exhibit pleiotropic reproductive abnormalities. Genes \& Dev. 9: 2266-2278.

Mangelsdorf, D.J., Thummel, C., Beato, M., Herrlich, P., Schütz, G., Umesono, K., Blumberg, B., Kastner, P., Mark, M., Chambon, P., and Evans,
R.M. 1995. The nuclear receptor superfamily: The second decade. Cell 83: 835-839.

Marselos, M. and Tomatis, L. 1992. Diethylstilboestrol: I, pharmacology, toxicology and carcinogenicity in humans. Eur. J. Cancer 28A: 1182 1189.

Õnate, S.A., Tsai, S.Y., Tsai, M.-J., and O'Malley, B.W. 1995. Sequence and characterization of a coactivator for the steroid hormone receptor superfamily. Science 270: 1354-1357.

Pettersson, K., Svensson, K., Mattsson, R., Carlsson, B., Ohlsson, R., and Berkenstam, A. 1996. Expression of a novel member of estrogen response element-binding nuclear receptors is restricted to the early stages of chorion formation during mouse embryogenesis. Mech. Dev. 54: 211-223.

Schatz, P.J. 1993. Use of peptide libraries to map the substrate specificity of a peptide- modifying enzyme: A 13 residue consensus peptide specifies biotinylation in Escherichia coli. Biotechnology 11: 1138-1143.

Scott, J.N. and Adejokun, F. 1980. Placental changes due to administration of diethylstilbestrol (DES). Virchows Arch. B Cell Pathol. 34: 261-267.

Smith, O.W. 1948. Diethylstilbestrol in the prevention and treatment of complications of pregnancy. Am. J. Obstet. Gynecol. 56: 821-827.

Tanaka, S., Kunath, T., Hadjantonakis, A.K., Nagy, A., and Rossant, J. 1998. Promotion of trophoblast stem cell proliferation by FGF4. Science 282: 2072-2075.

Tremblay, G.B., Tremblay, A., Copeland, N.G., Gilbert, D.J., Jenkins, N.A., Labrie, F., and Giguère, V. 1997. Cloning, chromosomal localization and functional analysis of the murine estrogen receptor $\beta$. Mol. Endocrinol. 11: 353-365.

Vanacker, J.-M., Bonnelye, E., Chopin-Delannoy, S., Delmarre, C., Cavailles, V., and Laudet, V. 1999. Transcriptional activities of the orphan nuclear receptor ERR $\alpha$ (estrogen receptor-related receptor- $\alpha$ ). Mol. Endocrinol. 13: 764-773.

Wendling, O., Chambon, P., and Mark, M. 1999. Retinoid X receptors are essential for early mouse development and placentogenesis. Proc. Natl. Acad. Sci. 96: 547-551.

Xie, W., Hong, H., Yang, N.N., Lin, R.J., Simon, C.M., Stallcup, M.R., and Evans, R.M. 1999. Constitutive activation of transcription and binding of coactivator by estrogen-related receptors 1 and 2. Mol. Endocrinol. 13: 2151-2162.

Xie, W., Barwick, J.L., Downes, M., Blumberg, B., Simon, C.M., Nelson, M.C., Neuschwander-Tetri, B.A., Brunt, E.M., Guzelian, P.S., and Evans, R.M. 2000. Humanized xenobiotic response in mice expressing nuclear receptor SXR. Nature 406: 435-439.

Yang, C. and Chen, S. 1999. Two organochlorine pesticides, toxaphene and chlordane, are antagonists for estrogen-related receptor $\alpha-1$ orphan receptor. Cancer Res. 59: 4519-4524.

Zhou, G., Cummings, R., Li, Y., Mitra, S., Wilkinson, H.A., Elbrecht, A., Hermes, J.D., Schaeffer, J.M., Smith, R.G., and Moller, D.E. 1998. Nuclear receptors have distinct affinities for coactivators: Characterization by fluorescence resonance energy transfer. Mol. Endocrinol. 12: $1594-1604$.- 


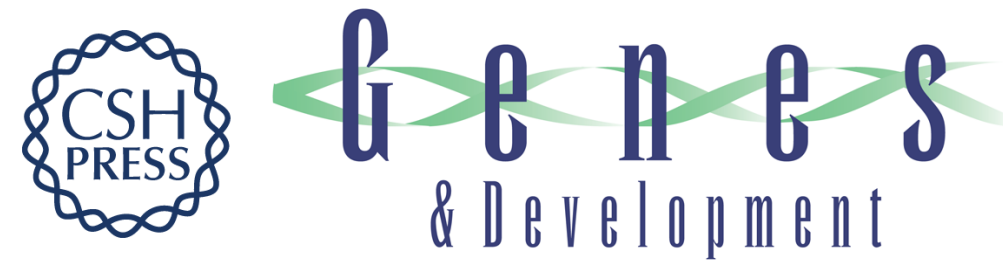

\section{Diethylstilbestrol regulates trophoblast stem cell differentiation as a ligand of orphan nuclear receptor ERR $\beta$}

Gilles B. Tremblay, Tilo Kunath, Denis Bergeron, et al.

Genes Dev. 2001, 15:

Access the most recent version at doi:10.1101/gad.873401

References This article cites 33 articles, 13 of which can be accessed free at: http://genesdev.cshlp.org/content/15/7/833.full.html\#ref-list-1

License

Email Alerting Receive free email alerts when new articles cite this article - sign up in the box at the top Service right corner of the article or click here.

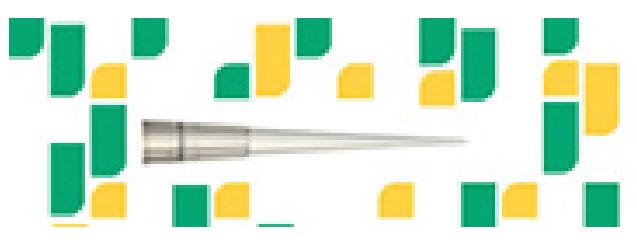

Focused on your science. 